\title{
Status społeczno-zawodowy niewidzących kobiet w wieku 50+
}

\author{
The social and professional status of blind women in \\ the age of $50+$
}

Streszczenie. Sytuacja osób niepełnosprawnych, a szczególnie niepełnosprawnych kobiet, na przestrzeni dziejów ludzkości była niejednoznaczna oraz wysoce zróżnicowana, tak w kwestii prezentowanych postaw społecznych, jak i uznania prawa do aktywnego udziału w życiu społecznym, samorealizacji zawodowej oraz osobistej. Czasy obecne, mimo postulowania równouprawnienia osób z niepełnosprawnością we wszystkich możliwych sferach funkcjonowania i niczym nieograniczonej dostępności do dóbr nauki, kultury, edukacji i zatrudnienia stawiają osoby niepełnosprawne, chociażby z racji obecnych konsekwencji niepełnosprawności, w pozycji mniejszych szans i ograniczeń na realizację indywidualnych planów oraz spełnianie wyzwań stawianych przez czasy współczesne i siebie samego. Stąd w treści danego artykułu podjęto próbę wyjaśnienia istniejącej niskiej aktywności niepełnosprawnych wzrokowo kobiet w kwestii angażowania się w życie społeczne i zawodowe.

Słowa kluczowe: niepełnosprawność, osoba niepełnosprawna, niepełnosprawność wzrokowa, osoba z niepełnosprawnością wzrokową, edukacja, rehabilitacja.

Summary. The situation of disabled people, and especially disabled women, was ambiguous over the centuries and highly diversified, both in the social attitudes towards them, as in the recognition for their active participation in social life, and the ability to achieve professional and personal self-fulfillment. Current times, despite the postulate of equal-rights for disabled people in every possible sphere of life and unrestricted access to knowledge, culture, education and employment, put disabled people, just because of the consequences of disability, in the position of lesser chances and limitations for realization of their individual plans, and achieving goals established by today's society and themselves. Because of that the article undertakes an attempt to explain the existing minimal activity of visually impaired women in the light of their commitment to social and professional life.

Keywords: disability, disabled person, visual disability, person with impaired sight, education, rehabilitation. 


\section{4 | Marzenna Zaorska}

\section{Wprowadzenie}

Sytuacja kobiet na przestrzeni dziejów ludzkości była nie tylko niezwykle skomplikowana i trudna wręcz ze społecznego, socjo-kulturowego, historyczno-kulturowego, mentalnego punktu widzenia oraz zdeterminowana i zdominowana licznymi stereotypami, w tym stereotypami roli i miejsca w strukturach życia społeczno-politycznego, rodzinnego, edukacyjno-zawodowego czy sportowo-rekreacyjnego. Egzemplifikowało się to w wymiarze prawnym, dostępności do określonych obszarów aktywności indywidualnej i zbiorowej, możliwości uzyskiwania autonomii w kwestiach decyzyjnych, między innymi w kwestii decydowania o sobie i własnych preferencjach oraz artykulacji potrzeb, obejmujących różne sfery bytu ludzkiego, np. sferę potrzeb biologicznych czy osobistych wyborów.

Wątki stereotypizacji społecznej roli kobiet oraz istoty ich płci znajdujemy już w kulturze społeczeństw pierwotnych, a zatem na wszystkich kolejnych epokach historycznych - od starożytności po czasy współczesne. Są one również obecne $\mathrm{w}$ wielu działach naukowych, literackich, religijnych (np. Biblia, Koran), w koncepcjach psychologicznych, definiujących rozwój ludzkości i osoby ludzkiej oraz pokazujących jego uwarunkowania, np. w koncepcji archetypów, opracowanych przez Carla Junga, które są zakorzenione i utrwalone w ludzkiej w nieświadomości w postaci wewnętrznego wyobrażenia czy wyobrażeń o sobie, innych i społeczeństwie. Istnieją też aktualnie niemal we wszystkich wymiarach funkcjonowania człowieka i cywilizacji ponowoczesnej oraz $\mathrm{w}$ ich skonkretyzowanych elementach, $\mathrm{np}$. w systemie edukacji, a ściślej w akceptowanych przez ten system chociażby podręcznikach szkolnych.

Co prawda czasy obecne charakteryzują się podejmowaniem działań na rzecz zmiany dotychczasowych norm związanych ze stereotypizacją i społecznym naznaczeniem możliwości, miejsca i roli określonych osób, grup i społeczeństw, jednakże zdaje się, że droga ku tym zmianom wiedzie nie tylko przez zmianę unormowań wyrażonych w obowiązującym prawie, ale przede wszystkim przez o wiele trudniejszą zmianę zakorzenionych historycznie i kulturowo mentalnych percepcjach, co do których jakiekolwiek transformacje są o wiele bardziej skomplikowane i niejednoznaczne.

$\mathrm{Na}$ tle powyższych analiz rysuje się możliwy, ale również realny obraz społecznie i indywidualnie ugruntowanych stereotypów wobec kobiety z niepełnosprawnością, jako tej nie tylko naznaczanej z powodu swojej płci, ale także samej niepełnosprawności i adekwatnych jej konsekwencji. Stereotyp ów każe myśleć o kobiecie niepełnosprawnej jako o mogącej 
jeszcze mniej niż kobieta pełnosprawna. Jako o osobie potrzebującej pomocy, wsparcia, wyręczania i jednocześnie na tę pomoc, wsparcie i wyręczanie oczekującej, osobie mającej poważnie ograniczone możliwości społecznego funkcjonowania i społecznej aktywności, samorealizacji i autonomii, z wieloma ograniczeniami w obszarze edukacyjnym, zawodowym, rodzinnym, czasu wolnego.

Taki obraz kobiety niepełnosprawnej istniał $\mathrm{i}$ istnieje jeszcze $\mathrm{w}$ wielu wyobrażeniach po dzień dzisiejszy. Istniał w kontekście historycznym, $\mathrm{z}$ tą różnicą, że nawet jeśli zaakceptowano prawo kobiety niepełnosprawnej w ogóle do życia, to już nie dane jej było pokazanie pełni swoich możliwości, poza tymi odgórnie przypisanymi przez stereotyp roli, którą ma pełnić w społeczeństwie, przy posiadaniu poważnie zawężonych niepełnosprawnością ograniczeń. I tak, dla przykładu wielu kobietom z niepełnosprawnością wzrokową w starożytności odmawiano prawa do życia, czy nawet pozbawiano życia (np. Sparta). Natomiast Żydzi sprzedawali niewidome dziewczęta możnym, którzy zmuszali je do żebractwa lub prostytucji.

\section{Sytuacja osób niepełnosprawnych ze szczególnym uwzględnieniem kobiet niepełnosprawnych wzrokowo na przestrzeni rozwoju ludzkości}

W zależności od sposobów zdobywania środków do życia, zwłaszcza rozwoju narzędzi produkcji, na przestrzeni dziejów ludzkości różne fizyczne i psychiczne niepełnosprawności zaliczano wprost do kategorii upośledzeń (Kirejczyk, 1981, s. 12). Osoby niepełnosprawne posiadające niepełnosprawność słuchową, wzrokową, uszkodzenia anatomiczne, niepełnosprawność intelektualną (zwłaszcza głębszą) były (i są) nie tylko łatwo dostrzegalne, zwracały na siebie uwagę, lecz wymagały szczególnej (specjalnej) troski - utrzymania lub wzmożonej opieki (względnie stawały się włóczęgami, żebrakami, pasożytami społecznymi) (tamże, s. 11).

Na Międzynarodowym Forum UNESCO w Paryżu w czerwcu 1997 roku wyróżniono kilka kolejno występujących po sobie etapów historycznych, odnoszących się do percepcji oraz postaw wobec osób niepełnosprawnych:

1. Etap filantropijny - człowiek niepełnosprawny traktowany jest jako chory (upośledzony), niezdolny do pracy i życia w społeczeństwie, wymagający pomocy (miłosierdzia) i opieki (filantropia). 
2. Etap „towarzystw dobroczynności” - człowiek niepełnosprawny skazany jest na pomoc i opiekę w różnego rodzaju instytucjach charytatywno-filantropijnych.

3. Etap podstawowych praw - uznaje, że człowiek niepełnosprawny też może mieć określone prawa, np. prawo do nauki.

4. Etap prawa do różnych możliwości - upowszechnienie kształcenia młodego pokolenia powoduje wzrost zainteresowania ludźmi niepełnosprawnymi; zwraca się uwagę na potrzebę zapewnienia osobom niepełnoprawnym niezbędnych warunków, np. do nauki oraz podejmuje się próby przygotowania pojedynczych jednostek do zawodu.

5. Etap prawa do integracji - oznacza uznanie, że w społeczeństwie istnieje grupa ludzi (niepełnosprawnych), która powinna mieć zapewnione warunki do życia z innymi i wśród innych, dąży się do pełnej integracji ludzi niepełnoprawnych w społeczeństwie; drogą do integracji jest przygotowanie do zawodu i życia społecznego (Międzynarodowe Forum UNESCO, 1998, s. 33-38).

Podejście do zjawiska ludzkiej niepełnosprawności od wieków kształtowały dwa systemy religijne, które wywarły największy wpływ na współczesną kulturę europejską, są to judaizm i chrystianizm. Według religii żydowskiej, niepełnosprawność (kalectwo) jest karą Boga za popełnione grzechy, podobnie jak choroba (Chodkowska, 1994, s. 113). W Nowym Testamencie znajdujemy wskazanie, że niepełnosprawność (kalectwo) może pozostawać w związku z przyczynowym z grzechem (tamże, s. 115).

Pewne odstępstwo znajdujemy w religii egipskiej w stosunku do osób niesłyszących. Uszkodzenie funkcji słuchowej bowiem traktowano jako szczególne wyróżnienie, dar bogów, którzy wybranym przez siebie ludziom odbierali mowę, chcąc ich w ten sposób uchronić od grzeszenia za pomocą słowa. Osoby niesłyszące były na ogół szanowane i czczone, gdy tymczasem inne dzieci niepełnosprawne były wyrzucane do Nilu.

Buddyzm, który oparł etykę i normy postępowania człowieka na miłości bliźniego, braterstwie i równości wszystkich ludzi, niezależnie od rasy czy pochodzenia, nakazywał traktować dobrze i z należną godnością. Jednak zdarzały się wśród wyznawców buddyzmu przypadki pozostawiania dzieci niepełnosprawnych w dżunglach.

Islam postulował całkowite poddanie się „woli bożej”, pełną jej uległość oraz składać jałmużnę, polegającą na oddawaniu części swych plonów, dochodów na potrzeby ludzi biednych, wymagających pomocy, a więc i niepełnosprawnych fizycznie i/lub psychicznie. Koran popiera troskę o zapewnienie niepełnoprawnym godnego bytu (Kirejczyk, 1981, s. 15). 
Religia chrześcijańska początkowo zalecała litość w stosunku do wszelkiego rodzaju nieszczęśliwych. W późniejszym jednak okresie, opierając się na poglądach św. Augustyna, uznała wielu niepełnosprawnych za niezdolnych do zrozumienia i przyjęcia wiary chrześcijańskiej. Święta inkwizycja nakazywała niepełnosprawnych intelektualnie, chorych psychicznie i zachowujących się niewłaściwie, np. w czasie modlitwy, torturować, łamać kołem, pławić, a nawet palić na stosach jako opętanych przez szatana. W tym samym czasie epileptyków wpadających w ekstazę uważano za nawiedzonych przez Ducha Świętego i zalecano czcić, a samą chorobę nazywano „chorobą św. Walentego". Ludzi niewidomych i częściowo niepełnosprawnych uważano za szczególnie miłych Bogu. Zrodziło to przekonanie o większej skuteczności ich modłów, co stworzyło tym ludziom lepsze warunki egzystencji (tamże, s. 16). „Miłość bliźniego” i uzależnienie zbawienia od spełniania dobrych, miłosiernych uczynków spowodowały, że najpierw dla starców, chorych, sierot, niepełnosprawnych ruchowo i niewidomych zakładano przytułki, azyle, swego rodzaju schroniska, które zostały nazwane zakładami charytatywnymi lub opiekuńczymi (tamże, s. 16).

Poziom warunków życia, zwłaszcza materialnych, zawsze odbijał się w sposób istotny na losach osób niepełnosprawnych. W krańcowo złych warunkach, zwłaszcza w okresie wojen, klęsk i głodu dochodziło nawet do unicestwienia wielu osób niepełnosprawnych jako ludzi nie nadających się do realizacji trudnych zadań i będących dla społeczeństwa ciężarem (tamże, s. 13).

Dzieciobójstwo ze względów biologiczno-medycznych było, np. w starożytnej Grecji nie tylko dopuszczalne, ale wręcz wchodziło w zakres obywatelskich obowiązków. Panował tu kult ciała i siły. Osoby niepełnosprawne nie były uważane za członków społeczeństwa, dlatego eliminowano je przez uśmiercenie (Majewski, 1995, s. 51). Nie tylko w Sparcie, ale również w innych miastach-państwach pozbawiano życia, np. dzieci wątłe i chore, zakładając, że w przyszłości stałyby się ciężarem zagrażającym społeczeństwu. Ocena stanu dziecka i wydanie wyroku leżało w kompetencjach różnych osób, w zależności od obyczajów i praw. I tak, na przykład w Atenach o porzuceniu niemowlęcia decydował ojciec, natomiast w Sparcie przedstawiano dziecko zaraz po urodzeniu do oceny specjalnej komisji starszych obywateli, którzy badali jego budowę i zdrowie oraz orzekali, czy ma być przeznaczone na wychowanie, czy też do zgładzenia (Chodkowska, 1994, s. 120).

Grecja, jak podaje M. Chodkowska, pod względem postaw wobec osób niepełnosprawnych nie była w starożytności wyjątkiem. W Rzymie obowiązywały podobne normy. Ogłoszone w 499 r. p.n.e. Lex duodecim tabularum zniosło wprawdzie nieograniczoną władzę ojca nad rodziną, który uprzednio 
był panem życia i śmierci wszystkich jej członków, ale jednoczenie to samo prawo nakazywało uśmiercanie dzieci słabych i kalekich (tamże, s. 120).

Ocenianie wartości życia ludzkiego w oparciu o kryteria biologiczno-medyczne nie było w starożytności powszechnie akceptowane. Odmienne postawy prezentowali niektórzy filozofowie. Kwestionowali oni ocenianie ludzi biorąc pod uwagę ich wygląd czy stan zdrowia - jest to widoczne, np. w ideach głoszonych przez stoików, przyjmujących założenie o równości wszystkich ludzi, która wynika $z$ faktu, iż jedynym dobrem, samowystarczalnym i niepodzielnym jest cnota. Można więc być tylko albo dobrym, albo złym. Bogactwo, uroda fizyczna, stanowiska społeczne czy nawet zdrowie są wartościami obojętnymi: nie są ani dobre, ani złe. Tendencje do łagodzenia dramatycznych przejawów negatywnych postaw wobec niepełnosprawności wykazywali także starożytni lekarze. Nie byli oni jednak w stanie, podobnie jak i filozofowie, doprowadzić do istotniejszych zmian w tym zakresie. Negatywny stosunek do niepełnosprawności wiązał się bowiem bardzo silnie z ekonomicznymi potrzebami ówczesnej ludności i to właśnie lęk przed niezaspokojeniem tych potrzeb tkwił u podstaw eliminowania z życia społeczności osób będących dla niej obciążeniem (tamże, s. 120-121). Skrajnie negatywne postawy wobec niepełnosprawności utrzymywały się przez wieki, złagodziły je dopiero wpływy współczesnego chrześcijaństwa.

W czasach współczesnych niektóre ludy pierwotne, jeszcze do niedawna, uśmiercały niepełnosprawne dzieci. Na przykład wśród Masajów dzieci fizycznie niepełnosprawne lub bardzo słabe były zabijane bezpośrednio po urodzeniu, w plemieniu Wogeo na Nowej Gwinei - grzebane je żywcem, a u Jukunów (Sudan) - porzucano w gąszczach leśnych lub jaskiniach (Wright, 1965, s. 279). W tym miejscu należy wspomnieć, że wyniszczanie osób niepełnosprawnych było prawnie sankcjonowane i powszechnie stosowane w hitlerowskich Niemczech (Twardowski, 1999, 35).

Najistotniejszym czynnikiem zmieniającym podejście do osób niepełnosprawnych, w tym do niepełnosprawnych kobiet był rozwój i postęp nauki. W starożytności, w okresie pozbawiania nawet życia dziewczynek niewidzących, potem w okresie rozpowszechniania się opiekuńczych zakładów charytatywnych, zwłaszcza w okresie Oświecenia i w latach następnych, pojawiły się poczynania zmierzające do wyjaśnienia istoty i przyczyn niewidzenia. W ten sposób powstawały różne, rozwijające się wciąż gałęzie nauki. One to stopniowo wyjaśniały tajemnicze początkowo zjawiska niepełnosprawności (upośledzeń) (Kirejczyk, 1981, s. 17). Ówczesna działalność na rzecz osób niepełnosprawnych ograniczała się głównie do zapewnienia im niezbędnej opieki i zaspokojenia podstawowych potrzeb biologicznych. 
W wyniku rozwoju i postępu nauki, w czasach nowożytnych, pod koniec XVIII wieku, uczyniony został następny krok. Zaczęły powstawać pierwsze szkoły dla dzieci niepełnosprawnych - niesłyszących, niewidomych. Następnie obserwujemy rozwój działalności na rzecz niepełnosprawnych, która została określona jako rehabilitacja. Była ona jednak ukierunkowana na życie i pracę w formach specjalnie tworzonych dla tych osób. Po drugiej wojnie światowej, kiedy zaczął się wielki rozwój działalności rehabilitacyjnej pojawiło się pojęcie „integracji społecznej” i „reintegracji społecznej”, czyli włączenia osób niepełnosprawnych w normalne życie i pracę społeczeństwa (Majewski, 1995, s. 51).

Na zmianę sytuacji osób niepełnosprawnych wzrokowo, w tym niewidzących kobiet, znaczący wpływ miała działalność założonego w latach 1910-1911 przez Różę Czacką Towarzystwa Opieki nad Ociemniałymi. W ramach tego towarzystwa funkcjonowało między innymi ognisko dla niewidomych kobiet z nauką koszykarstwa, plecionkarstwa i trykotarstwa, schronisko dla niewidomych staruszek. Realizowano patronat nad niewidomymi rodzinami (Sękowska, 1981).

Mówiąc o systemie wsparcia osób z niepełnosprawnością wzrokową w Polsce trudno pominąć działalność Polskiego Związku Niewidomych (PZN). W obecnej nazwie istnieje od 1951 roku (poprzednikiem organizacji był Związek Pracowników Niewidomych RP, założony w 1946 roku) (Kuczyńska, Kwapisz, Kwapisz, 1996). PZN organizuje oraz realizuje szeroką i niezbędną pomoc merytoryczną, informacyjną, rehabilitacyjno-edukacyjną oraz rzeczową swoim podopiecznym. Obejmuje też wymaganym wsparciem członków rodziny osoby niewidomej i/lub poważnie niedowidzącej.

\section{Sytuacja niepełnosprawnych wzrokowo w aktualnej rzeczywistości ze szczególny uwzględnieniem wyników zrealizowanych badań własnych}

Na podstawie powyższych dyskusji pojawia się pytanie o sytuację niewidomych kobiet we współczesnej rzeczywistości społecznej. Pytanie tym bardziej uzasadnione, że aktualna rzeczywistość w naszym kraju, po transformacji ustrojowej, zmieniła istotnie wiele obszarów życia społecznego, także obszar pracy, zatrudnienia oraz możliwej aktywności zawodowej. Rozwiązaniu bowiem uległa znaczna część zakładów pracy chronionej i tzw. spółdzielni inwalidzkich, w których osoby niepełnosprawne dorosłe, także niewidome, znajdowały zatrudnienie, a dzięki temu możliwość zarobkowania 
i utrzymania siebie oraz własnej rodziny. To spowodowało wysokie bezrobocie nie tylko w środowisku osób niepełnosprawnych czy pełnosprawnych, ale też zróżnicowane zachowania ze strony ludzi z niepełnosprawnością. Zachowania, które można zdefiniować jako pozytywne polegają na ukierunkowaniu na poszukiwanie alternatyw zatrudnienia, np. w tzw. otwartym rynku pracy, dążność ku edukacji i poszerzaniu wiedzy, poprzez studia wyższe i inne oraz negatywne - charakteryzują się oczekiwaniem na pomoc i zadowoleniem z posiadanych świadczeń z tytułu niepełnosprawności.

Statystyki Polskiego Związku Niewidomych dowodzą, że w roku 2010 w szkołach wyższych kształciło się 530 niewidomych. Wśród nich 233 na studiach pierwszego stopnia (licencjackich), 262 na studiach drugiego stopnia (magisterskich uzupełniających), 31 na studiach podyplomowych, 14 na studiach doktoranckich. Badania naukowe, które zrealizowano w tym samym roku na 427 uczelniach wyższych pokazały, że:

1) stanowisko/funkcja pełnomocnika rektora ds. niepełnosprawnych studentów istniała w $30 \%$ państwowych i $4 \%$ niepaństwowych uczelni, $11 \%$ państwowych i $14 \%$ niepaństwowych uczelni nie posiadało żadnej komórki odpowiadającej za studentów niepełnosprawnych;

2) istnienie możliwości kształcenia studentów z niepełnosprawnością wzrokową deklarowało $27 \%$ uczelni państwowych i 53\% uczelni niepaństwowych, a na niektórych specjalnościach nawet 40\% państwowych i $18 \%$ niepaństwowych uczelni wyższych. Brak jakichkolwiek możliwości studiowania dla osób niepełnosprawnych wzrokowo był obecny w 15\% państwowych i $23 \%$ niepaństwowych uczelni wyższych;

3) wśród specjalności dostępnych dla studiowania niepełnosprawnym wzrokowo studentom wymieniano między innymi następujące: marketing i zarządzanie, ekonomia, administracja i wybrane specjalności techniczne;

4) niepełnosprawni wzrokowo kandydaci na studia zadeklarowali chęć studiowania w 58\% uczelni państwowych i 25\% uczelni niepaństwowych;

5) możliwość dostępu niepełnosprawnych wzrokowo studentów do elektronicznych wariantów konspektów wykładów, zajęć praktycznych oraz seminaryjnych zadeklarowało $45 \%$ uczelni państwowych i $47 \%$ uczelni niepaństwowych, zaś możliwość korzystania ze specjalistycznego oprogramowania - 34\% uczelni państwowych i 23 uczelnie niepaństwowe; możliwość przetransformowania materiałów drukowanych na elektroniczne - 32\% państwowych i $23 \%$ niepaństwowych uczelni; pomocy asystenta - 23\% uczelni państwowych i $11 \%$ uczelni niepaństwowych; nagrywania wykładów - 50\% wszystkich badanych uczelni; 
6) wśród propozycji poprawy sytuacji niewidzących i słabo widzących studentów podano: lepsze wyposażenie w nowoczesne urządzenia i sprzęt elektroniczny oraz elektroniczno-optyczny, w komputery z właściwym oprogramowaniem, skanery, rzadziej wskazywano: stworzenie biblioteki posiadającej publikacje wydane alfabetem Braille'a oraz systemu wolontariatu wśród pełnosprawnych studentów (Fundacja Instytut Rozwoju Regionalnego, 2007).

$\mathrm{Na}$ podstawie zrealizowanych analiz można sądzić, że w wyjątkowo skomplikowanej sytuacji, jak pokazuje doświadczenie życia społecznego w kontekście możliwości pracy, znajdują się osoby w wieku tzw. średniej dorosłości, aktualnie dość popularnie określanym jako 50+, w tym kobiety z niepełnosprawnością wzrokową.

W celu poznania sytuacji kobiet z niepełnosprawnością wzrokową $\mathrm{w}$ wieku 50+ przeanalizowano wybrane informacje uzyskane od beneficjentek uczestniczących w projekcie pt. „Wsparcie osób niewidomych na rynku pracy" (Zaorska, 2009, s. 395-406, 2011, s. 181-196, 2013, s. 175-200, 2013, s. 37-57). Realizatorem projektu był Polski Związek Niewidomych (PZN). Projekt był współfinansowany ze środków Państwowego Funduszu Rehabilitacji Osób Niepełnosprawnych oraz środków Unii Europejskiej (Europejskiego Funduszu Społecznego Kapitał Ludzki). Był realizowany jako projekt nr 1 - czas realizacji projektu: kwiecień-grudzień 2009 roku oraz projekt nr 2 - czas realizacji maj-grudzień 2010 roku.

Projekt nr 1 przygotowano pod adresem osób młodych oraz osób znajdujących się w okresie aktywizacji zawodowej, z poważną (całkowita i/lub prawie całkowita) utratą wzroku, które potrzebują specjalistycznej pomocy w zaprojektowaniu własnej kariery edukacyjnej i zawodowej. Prace nad wykonaniem danego projektu odbywały się w oparciu o dwa zasadnicze kierunki. Pierwszy - obejmował beneficjentów, którzy realizowali projekt w skali lokalnej (300 osób). Drugi - podopiecznych Towarzystwa Opieki nad Ociemniałymi; za wykonanie tego elementu odpowiadało Towarzystwo (200 osób). Warunkiem włączenia do udziału w projekcie na poziomie lokalnym były następujące kryteria: posiadanie orzeczenia o stopniu niepełnosprawności, kształcenie się w ostatniej klasie szkoły ogólnodostępnej lub integracyjnej na poziomie gimnazjalnym lub ponadgimnazjalnym lub bycie absolwentem tych szkół nie więcej niż do 12 miesięcy od ich ukończeniu, ostrość wzroku mniejsza niż 3/60 - 0,005 i/lub pole widzenia mniejsze niż 20 stopni, ukończone 16 lat. Każdy uczestnik mógł skorzystać z indywidualnych spotkań z tyflopedagogiem, psychologiem, lekarzem okulistą, doradcą zawodowym oraz prawnikiem. Zatem był kierowany do udziału w określo- 


\section{2 | Marzenna Zaorska}

nych formach rehabilitacji społecznej oraz wybranych szkoleniach, warsztatach i stażach zawodowych.

$\mathrm{Z}$ uwagi na fakt, że omawiany projekt uzyskał pozytywną opinię uczestników oraz osób odpowiedzialnych za jego ewaluację PZN podjął starania na rzecz kontynuacji podobnych działań w kolejnych latach. Stąd od maja 2010 roku przystąpiono do realizacji kolejnej edycji projektu „Wsparcie osób niewidomych na rynku pracy 2" (www.pzn.org.pl). Edycja druga, podobnie jak pierwsza, była realizowana w partnerstwie z Państwowym Funduszem Rehabilitacji Osób Niepełnosprawnych (PFRON) oraz Towarzystwem Opieki nad Ociemniałymi w Laskach, współfinansowana ze środków Europejskiego Funduszu Społecznego oraz krajowych środków PFRON, adresowana do 700-osobowej grupy beneficjentów.

Celem była aktywizacja społeczno-zawodowa osób niewidomych poszukujących pracy i pozostających bez zatrudnienia. Uczestnicy mieli otrzymać wsparcie i pomoc w budowaniu własnej ścieżki rozwoju zawodowego. Kwalifikowano osoby, które spełniały następujące kryteria: ukończony 16 rok życia i nie przekroczony wiek 64 lat, bycie osobą nieaktywną zawodowo, poszukującą pracy, posiadanie orzeczenia o niepełnosprawności w stopniu znacznym z symbolem przyczyny niepełnosprawności 04-O, lub równoważne z udokumentowanym stopniem utraty wzroku: ostrość wzroku (po korekcji) w oku lepszym równa lub poniżej 3/60 $(0,05)$ lub zawężenie pola widzenia poniżej 20 stopni, lub posiadanie orzeczenia o niepełnosprawności - umiarkowanym stopniu niepełnosprawności z symbolem przyczyny 04-O lub równoważne, $z$ udokumentowanym stopniem utraty wzroku.

Druga edycja projektu była realizowana na poziomie lokalnym i ogólnopolskim. Na poziomie lokalnym uczestnicy otrzymywali pomoc w postaci: indywidualnych diagnoz opracowanych przez lekarza, psychologa i tyflopedagoga, określenia indywidualnych ścieżek zawodowych, opracowanych przez doradców zawodowych we współpracy z różnymi specjalistami zgodnie $\mathrm{z}$ indywidualnymi potrzebami uczestnika. Przewidziano też możliwość spotkania $\mathrm{z}$ wybranym/wybranymi specjalistą/specjalistami pod kątem omówienia i przekonsultowania indywidualnej ścieżki zawodowej.

$\mathrm{Na}$ podstawie indywidualnych diagnoz wybrani beneficjenci, już na poziomie ogólnokrajowym, otrzymywali dodatkową pomoc w postaci: rehabilitacji społecznej, ułatwiającej wchodzenie w interakcje społeczne, pomocy w znalezieniu staży zawodowych oraz miejsc pracy, warsztatów aktywizacji zawodowej, warsztatów psychologicznych i edukacyjnych dla rodzin/opiekunów osób niewidomych, szkoleń, m.in.: zarządzanie bazami danych, założenie i prowadzenie własnej działalności gospodarczej, obsługa biura i recep- 
cji, pracownik call center oraz innych szkoleń zawodowych i kursów, m.in.: ECDL, język angielski, warsztaty dziennikarskie. Uczestnikom proponowano dodatkowe formy rehabilitacji społecznej: czynności życia codziennego, techniki komunikacji, w tym techniki komputerowe, usprawnianie widzenia i dobór pomocy optycznych i nie-optycznych, orientacja przestrzenna, samodzielne, bezpieczne, skuteczne poruszanie się, oddziaływanie psychologiczne i tyflopedagogiczne, kreowanie wizerunku w wymiarze maksymalnym 15 godzin na każdą z podanych form.

Ogółem z udziału w dwóch edycjach projektu, z Okręgu Warmińsko-Mazurskiego PZN skorzystały 104 osoby (100\%), w tym z edycji pierwszej 45 osób (43\%), z edycji drugiej 59 osób (57\%). Wśród ogółu uczestników kobiet kwalifikujących się w wieku 50-ciu lat i powyżej było 15 (14\% w relacji do ogółu beneficjentów i $100 \%$ w stosunku do ogółu kobiet w wieku 50+). Konkretnie w kryteriach wiekowych 50-55 lat były 4 kobiety (27\%), 56-61 lat - 11 (73\%). Wszystkie były członkami Polskiego Związku Niewidomych.

Bardziej szczegółowa analiza badanych kobiet pozwala stwierdzić, że aż 14 (93\%) kształciło się w szkolnictwie wyłącznie masowym, ogólnodostępnym, a tylko jedna (7\%) początkowo w szkolnictwie masowym, a kolejno w specjalnym. $34 \%$ badanych (5 kobiet) zamieszkiwało małe miasto, 39\% miasto średniej wielkości (6 kobiet) i 27\% (4 kobiety) duże miasto. $60 \%$ badanych (9 kobiet) urodziło się i w okresie dzieciństwa zamieszkiwało wieś, 20\% (3 kobiety) miasto średniej wielkości, 13\% (2 kobiety) małe miasto, 7\% (1 kobieta) duże miasto.

Badane legitymowały się zróżnicowanym poziomem wykształcenia: 46\% (7 badanych) posiadało wykształcenie średnie (np. liceum/technikum ekonomiczne, handlowe, rolnicze, ogrodnicze, liceum ogólnokształcące), 27\% (4 badane) wykształcenie zawodowe (np. krawieckie), 13\% (2 badane) wykształcenie wyższe (studia rolnicze), po 7\% (po jednej badanej) wykształcenie podstawowe i pomaturalne.

Aktualnie badane kobiety utrzymywały się z renty z tytułu niepełnosprawności - 73\% (11 kobiet), z renty z tytułu niepełnosprawności i zasiłku pielęgnacyjnego - 20\% (3 osoby) i 7\% (1 osoba) z emerytury. Tylko jedna kobieta (7\%) nie była osobą zamężną i to $\mathrm{z}$ wyboru argumentowanego posiadaniem genetycznie uwarunkowanego uszkodzenia wzroku.

Do 5 lat pracowały dwie badane (13\%), do 10-ciu lat - dziesięć (67\%), a do 15 lat trzy (20\%). Spośród ogółu badanych pracę umysłową w okresie aktywności zawodowej wykonywało $54 \%$, fizyczną $-46 \%$. 
Problemy ze wzrokiem od urodzenia obecne były tylko u $20 \%$ badanych, od wczesnego i średniego dzieciństwa po $7 \%$, a aż u $66 \%$ pojawiały się one w okresie dorosłości. Natomiast jeśli chodzi o uszkodzenie widzenia, to w oku prawym więcej niż poczucie światła posiadało $66 \%$, poczucie światła $7 \%$ i niewidzenie $27 \%$, w oku lewym: więcej niż poczucie światła $80 \%$, poczucie światła $7 \%$ i niewidzenie $13 \%$. Żadna nie była osobą obuocznie niewidzącą.

Konkludując, należy zauważyć kilka znamiennych cech, charakteryzujących omawianą grupę badanych:

1) u większości uszkodzenie wzroku pojawiło się w okresie dorosłości i aktywności zawodowej;

2) dominowało wykształcenie średnie i na ogół ukierunkowane na obszar rolnictwa, co w aktualnej sytuacji na rynku pracy nie jest wystarczającym gwarantem uzyskania zatrudnienia;

3) wszystkie nie były osobami całkowicie niewidzącymi (posiadały resztki wzrokowe jednoocznie lub obuocznie);

4) prawie wszystkie utrzymywały się w renty z tytułu niepełnosprawności, a niektóre nawet renty wspomaganej zasiłkiem pielęgnacyjnym;

5) niemal wszystkie kształciły się w systemie szkolnictwa ogólnodostępnego;

6) ponad połowa urodziła się i w dzieciństwie kształciła w środowisku wiejskim.

\section{Podsumowanie}

Na podstawie opisanych danych powstaje pytanie o mało aktywne przejawianie działań na rzecz zmiany aktualnej sytuacji zatrudnieniowej badanych kobiet. I tu można podać kilka wskazań:

1) posiadany poziom wykształcenia oraz uzyskane specjalności zawodowe;

2) trudna sytuacja na rynku pracy, powodująca ukierunkowanie na pobieranie pomocy finansowej w postaci renty z tytułu niepełnosprawności;

3) mentalne nastawienie wobec posiadanej niepełnosprawności jako ogranicznika do podejmowania starań na rzecz aktywizacji na rynku pracy (także prawdopodobnie wynikające $\mathrm{z}$ wychowania w środowisku wiejskim);

4) koncentracja na stanie własnego zdrowia wpływająca na wykazywane nastawienie do bycia osobą aktywną w sferze pracy zawodowej. 
Powstaje też pytanie co można zrobić, aby zmienić istniejący stan rzeczy i w jaki sposób. Oczywistym jest, że odpowiedź na postawione pytanie nie jest sprawą łatwą. Chodzi bowiem nie tylko o kwestie edukacyjne (uzyskanie nowych kompetencji, istotnych z punktu widzenia współczesnego rynku pracy, np. posługiwania się nowymi technologiami informacyjnymi), psychoterapeutyczne (koncentrujące się uświadomieniu posiadanych możliwości i ukierunkowaniu na aktywność własną), czy rehabilitacyjne (nabycie umiejętności realizacji ważnych życiowo czynności i aktywności w warunkach ograniczenia widzenia), ale zasadniczo mentalne - polegające na zmianie własnego nastawienia do sytuacji ograniczeń obecnych jako możliwe (choć niekonieczne) konsekwencje uszkodzenia widzenia i samej siebie, jako osoby doświadczającej tych konsekwencji. Niewątpliwie można i należy podejmować próby przewartościowania i przetransformowania prezentowanych przez kobiety z niepełnosprawnością wzrokową nastawień wobec siebie i swojej niepełnosprawności, za pośrednictwem ciekawych propozycji dokształcenia, psychoterapii i rehabilitacji, a nawet zmiany unormowań prawnych i dostępności do należnych świadczeń, w tym świadczeń rzeczowo-finansowych, jednakże bez ukierunkowania samego człowieka na potrzebę takich zmian, nawet najlepsze projekty i programy aktywizacji zawodowej nie przyniosą zakładanego w nich efektu, poza niepotrzebnie wydatkowanymi, na ogół niemałymi, środkami pieniężnymi.

\section{Bibliografia}

Chodkowska M. (red.) (1994), Kulturowe uwarunkowania postaw wobec inwalidztwa oraz osób niepełnosprawnych. Ciągłość i możliwości zmiany. w: Człowiek niepetnosprawny. Problemy autorealizacji i społecznego funkcjonowania. Charisteria dla Profesor Zofii Sękowskiej, Wyd. UMCS, Lublin.

Fundacja Instytut Rozwoju Regionalnego (2007), Dostępność polskich szkół wyższych dla osób niepełnosprawnych, Kraków.

Kirejczyk K. (1981), Z historii pedagogiki specjalnej. w: Upośledzenie umysłowe. Pedagogika, K. Kirejczyk (red.), PWN, Warszawa.

Kuczyńska-Kwapisz J., Kwapisz J. (1996), Rehabilitacja osób niewidomych i słabowidzacych, Wydawnictwo Interart, Warszawa.

Majewski T. (1995), Rehabilitacja zawodowa osób niepetnosprawnych, CB-RRON, Warszawa.

Majewski T. (1997), Poradnik metodyczny dla nauczycieli pracujących z dziećmi z uszkodzonym wzrokiem w systemie integracyjnym, Wydawnictwo MEN, Warszawa. 
Międzynarodowe Forum UNESCO w Paryżu (1988), Obraz upośledzonego proponowany szerokiej opinii publicznej - czerwiec 1997, Biuletyn Informacyjny TWK, Warszawa, nr 3-4.

Sękowska Z. (1981), Tyflopedagogika, PWN, Warszawa.

Twardowski A. (1999), Rodzina a dziecko niepetnosprawne. W: Dziecko niepetnosprawne w rodzinie, I. Obuchowska (red.), WSiP, Warszawa.

Wright B. A. (1965), Psychologiczne aspekty fizycznego inwalidztwa, PWN, Warszawa.

Zaorska M. (2009), Projekt „Wsparcie osób niewidomych na rynku pracy” - refleksje $z$ realizacji pierwszego etapu. w: Osoba z niepetnosprawnościq. Opieka - TerapiaWsparcie, D. Baczała, J.J. Błeszyński, M. Zaorska (red.), Wydawnictwo UMK, Toruń, s. 395-406.

Zaorska M. (2011), Status zdrowotny, socjo-edukacyjny i zawodowy dorostych osób niewidomych i szczatkowo widzacych. w: Doradztwo zawodowe w sytuacji przemian ekonomiczno-społecznych XXI wieku, M. Gaber (red.), Oficyna Wydawnicza PROSPEKT, Dywity, s. 181-196.

Zaorska M. (2013), Czy niewidomi „widzq" siebie jako „Innych” w obszarze funkcjonowania intelektualnego i społecznego. w: Miejsce Innego we wspótczesnych naukach o wychowaniu. W poszukiwaniu pozytywów, I. Chrzanowska, Beata Jachimczak, Katarzyna Pawelczak (red.), Wydawnictwo UAM, Poznań, s. 175-200.

Zaorska M. (2013), Poczucie „inności” u osób niewidomych i osób z resztkami wzroku w sferze funkcjonowania psychicznego, fizycznego i emocjonalnego, „Interdyscyplinarne Konteksty Pedagogiki Specjalnej", nr 1, s. 37-57.

\section{Netografia}

Polski Związek Niewidomych www.pzn.org.pl, dostęp: 28.07.2010 r. 